\title{
Agronomic assessment of spent substrates for mushroom cultivation
}

\author{
Raquel Picornell-Buendía ${ }^{(1)}$, Arturo Pardo-Giménez ${ }^{(2)}$, José Arturo de Juan-Valero ${ }^{(1)}$ \\ (1) Escuela Técnica Superior de Ingenieros Agrónomos de Albacete. Castilla - La Mancha University. Campus Universitario \\ s/n. ES-E02071 Albacete (Spain).E-mail: mraquel.picornell@hotmail.com \\ ${ }^{(2)}$ Centro de Investigación, Experimentación y Servicios del Champiñón (CIES). C/Peñicas, s/n. Apartado 63. 16220 \\ Quintanar del Rey. ES-Cuenca (Spain).
}

Received on August 7, 2015; accepted on March 7, 2016.

Description of the subject. In this work the agronomic viability of substrates based on spent Agaricus bisporus Imbach (Lange) substrates (SAS) and spent Pleurotus ostreatus (Jacq.) P. Kumm. substrates (SPS) is studied.

Objectives. The aim of this work is the qualitative agronomic evaluation of SPS and SAS and the mixture of thereof in different proportions, such as lignocellulosic sources in new growing cycles of $P$. ostreatus.

Method. In addition to the commercial substrate used as a control reference, six different treatments are considered. In this experiment, SPS and SAS were mixed in different amounts. SAS was subjected to a heat treatment in a growing room ("cook out") and then to a maturation treatment which consisted of a controlled recomposting process in cameras. SPS was subjected to a pasteurizing heat treatment $\left(60^{\circ} \mathrm{C}-65^{\circ} \mathrm{C}, 8 \mathrm{~h}\right)$ and a progressive temperature decrease for at least $15 \mathrm{~h}$ to a "seeding" temperature $\left(25^{\circ} \mathrm{C}\right)$.

Results. SPS $(3,600 \mathrm{~g})+$ SAS $(2,400 \mathrm{~g})$ and SPS $(3,000 \mathrm{~g})+$ SAS $(3,000 \mathrm{~g})$ were prepared substrates that achieved acceptable crude protein content in their fruiting bodies. Additionally, we obtained higher ash content, lightness, yellow-blue (y-b) and red-green $(\mathrm{r}-\mathrm{g})$ chromaticity, breaking strength $(\mathrm{Bs})$, and compression energy $(\mathrm{CE})$ in these mushrooms. These values were higher than the mean values, and even higher than the commercial substrate.

Conclusions. Increased SAS participation in the mixture of the processed substrate (and the consequent reduction of SPS participation) resulted in mushrooms that require higher Bs, and CE. These formulation-based composts degraded by the growth of $P$. ostreatus, could be a low-cost substrate with selective and balanced nutrients for growth and development of oyster mushrooms.

Keywords. Pleurotus ostreatus, agricultural wastes, edible fungi, growing media.

\footnotetext{
Évaluation agronomique de substrats de culture épuisés pour la culture de champignons

Description de l'objet. Dans ce travail, est étudiée la viabilité agronomique de substrats à base de substrats épuisés de Agaricus bisporus Imbach (Lange) (SAS) et de substrats épuisés de Pleurotus ostreatus (Jacq.) P. Kumm. (SPS).

Objectifs. Le but de ce travail est l'évaluation agronomique qualitative de SPS et SAS et le mélange de ceux-ci dans des proportions différentes, telles que les sources lignocellulosiques, dans de nouveaux cycles de croissance de $P$. ostreatus.

Méthode. En plus du substrat commercial utilisé comme référence, six traitements différents sont considérés. Dans cette expérience, SPS et SAS sont mélangés en quantités différentes. SAS a été soumis à un traitement thermique dans une chambre de croissance et ensuite à un traitement de maturation qui consiste en un processus de compostage contrôlé en chambre. SPS a été soumis à un traitement thermique de pasteurisation $\left(60^{\circ} \mathrm{C}-65^{\circ} \mathrm{C}, 8 \mathrm{~h}\right)$ et à une diminution progressive de la température pendant au moins $15 \mathrm{~h}$ jusqu'à une température « d'ensemencement $~\left(25^{\circ} \mathrm{C}\right)$.

Résultats. SPS $(3,600 \mathrm{~g})+$ SAS $(2,400 \mathrm{~g})$ and SPS $(3,000 \mathrm{~g})+$ SAS $(3,000 \mathrm{~g})$ sont les substrats qui permettent d'obtenir une valeur acceptable de protéine dans leurs organes de fructification. De plus, nous avons obtenu des valeurs plus élevées des différents paramètres pour ces champignons, même plus élevées que pour les substrats commerciaux.

Conclusions. Une quantité plus importante de SAS dans le mélange (et la diminution conséquente de SPS) donne des champignons qui présentent une résistance à la rupture et une énergie de compression plus élevées. Ces types de composts dégradés par la croissance de $P$. ostreatus donnent des substrats de faible cout avec des nutriments sélectifs et équilibrés pour la croissance et le développement des pleurotes.

Mots-clés. Pleurotus ostreatus, déchet agricole, champignon comestible, substrat de culture.
} 


\section{INTRODUCTION}

The potential production of edible fungi is promising in the world market, as the current production is not sufficient to meet the demand. Most producing countries are importers too, since the average consumption in these countries is very high. Nutritionally, these species (Agaricus bisporus [Lange] Imbach, Pleurotus ostreatus [Jacq.] P. Kumm. and Lentinula edodes [Berkeley], among others) have moderate amounts of high quality proteins, contain all essential amino acids, and are rich in lysine, leucine, $\mathrm{C}$ and $\mathrm{B}$ vitamins, minerals, and other trace elements. Furthermore, their lipid levels and ratio of saturated to unsaturated fatty acids are low, they contain relatively high amounts of carbohydrates, and most species have high amounts of nutritionally valuable fibers (Chang et al., 1997).

Complementary to its nutritional properties, there are various health benefits known in the fields of medicine and therapeutics such as, antitumor, antibiotic, antifungal, and anti-inflammatory effects. Additionally, they are hypocholesterolemic, promote a healthy immune system, and have been widely used to treat cancer and HIV (Brizuela et al., 1998). Approximately, there are 300 species of cultivated mushrooms, but only 30 have been domesticated and just 10 are commercially grown. The most important cultivated mushroom worldwide is A.bisporus, followed by $P$. ostreatus and other species of the genus Pleurotus; L. edodes is third and other edible fungi are making headways in the market.

The reason for this commercial growth is because of the characteristics of the species of the genus Pleurotus (Sanchez, 2010). They have excellent organoleptic qualities, are easy to grow on a wide variety of substrates within a wide temperature range, and have a great potential in bioremediation processes. Moreover, little initial capital is required to establish warehouses for cultivation.

Unlike white mushrooms (A.bisporus), these do not require a chemically selective substrate because they can grow in nutrient media with a $\mathrm{C} / \mathrm{N}$ ratio between 30 and 300 (Rodriguez Barreal, 1987; Garcia Rollán, 2007). However, they need to grow in a specific biological environment with accompanying flora to protect and promote growth (Muez et al., 2002). Approximately, 13,500 t of this fungus are produced in Castilla - La Mancha (67\% of the national total) (Pardo et al., 2009).

The mushroom growing sector in Spain generates about $5 \cdot 10^{5} \mathrm{t}$ of spent compost, while the EU, as a whole, produces more than $3.5 \cdot 10^{6} \mathrm{t}$ (Pardo et al., 2009; Picornell et al., 2010). This lignocellulosic material, called mushroom spent substrate, can be used in various fields of agriculture: animal feed (Zadrazil, 1980b), amendments (Tajbakhsh et al., 2008), substrates of nurseries, nurseries (Medina et al., 2009), bioremediation (Faraco et al., 2009), aquaculture, vermiculture and biofuel (Pathak et al., 2009).

However these uses do not take advantage of the high volume generated annually, which accumulates in collection centers located in production areas of Spain. Furthermore these spent substrates are potential contaminants, as well as, a waste of energy. Pleurotus ostreatus has specific enzymes capable of degrading cellulose, lignin, phenols and polyphenols to $60 \%$ of the original content of the spent substrates (Picornell et al., 2010).

Currently, cereal straw (wheat in particular), with increasing constraints in availability and price, is virtually the only material used at an industrial scale for the production of P. ostreatus in Spain. The feasibility of using highly available alternative materials of a low cost is a line of research with great technological interest for improving productivity and reducing processing costs (Muez et al., 2002; Pardo et al., 2007; Pardo et al., 2009; Picornell et al., 2010).

According to various studies, the most commonly profitable and readily available spent substrate which generates high quality fruiting bodies for P. ostreatus (although this fungus can be grown on virtually any lignocellulosic substrate) is the trunk of Quercus humboldtii Bonpland (oak) (Garcia Rollán, 2007). Commercially in most industrial exploits, $2-4 \mathrm{~cm}$ long (Sanchez, 2010) pieces of winter cereal straw (wheat, barley, and rye) (Savalgi et al., 1994) are used in the substrate container for the production of Pleurotus genus and others, such as Pleurotus eryngii (DC.: Fr.) Quel., Pleurotus sajor-caju (Fr.) Singer, Pleurotus pulmonarius substrate (Fr.) Quél., etc. Khanna et al. (1982) refer to rice straw as the best substrate for the cultivation of P. sajor-caju, while wheat straw (which is similar to rice straw) is the best substrate for the cultivation of Pleurotus spp. (Bonatti et al., 2004).

Biodegradation of these cellulosic residues by Pleurotus spp. cultivation depends on the production of hemicellulases, cellulases, and ligninases enzymes (Kurt et al., 2010). These enzymes, and others, turn and degrade long and insoluble components of lignocellulosic materials into soluble components of low molecular weight that are taken by intracellular enzymes from fungi for their nutrition. Additionally, enzymes play an important role in the growth and development of fungi (Kuforiji et al., 2008).

However, lignocellulosic materials are generally low in protein content with insufficient values of nitrogen, phosphorus, and potassium (Vijay et al., 2007) for mushroom cultivation. Organic supplements are most commonly used in the preparation of growing substrates, with wheat and rice bran being the most popular (Wang et al., 2001; Peksen et al., 2009; Kurt et al., 2010). 
The aim of this work is the agronomic assessment of substrates based on spent A. bisporus (SAS) and spent P.ostreatus (SPS). The use of the remaining spent mushroom substrate after the cultivation of $P$. ostreatus in new production cycles would be an agronomically viable alternative to using wheat straw (WS), which is currently used exclusively as a base material. Economically, the use of the remaining spent mushroom substrate is beneficial when considering the high cost of WS, especially in drought years. This cereal farmer's by-product could be integrated through new formulations and methodologies while lowering production costs and reducing the environmental impact of unusual waste.

\section{MATERIALS AND METHODS}

\subsection{Analytical methodology used for the characterization of materials}

The characterization of raw materials and processed substrates was measured according to the following parameters: moisture (MAPA, 1994), pH (Ansorena, 1994), total nitrogen (Tecator, 1987; MAPA, 1994), ash
(MAPA, 1994), organic matter (Ansorena, 1994), C:N ratio, crude fiber (ANKOM, 2008), crude fat (ANKOM, 2009), nitrogen free extractives (NFE) (González et al., 1987), cellulose and neutral detergent-soluble (NDS) (ANKOM, 2005; ANKOM, 2006a; ANKOM, 2006b). Furthermore, the exploration of mites (Krantz, 1986) and nematodes (Nombela et al., 1983) was conducted in this experiment, showing negative results for tested substrates.

\subsection{Preparation of substrates and experimental design}

The only agronomic factor studied in this experiment is the type of base substrate with four block replicates. In accordance with the experimental design, seven different treatments were generated in the process, as well as a reference commercial substrate proper for Pleurotus species cultivation. In all treatments, except the control, $50 \mathrm{~g} \cdot \mathrm{kg}^{-1} \mathrm{CaSO}_{4}$ were added to the base material. $\mathrm{CaCO}_{3}$ (gypsum) was also added in varying amounts (Figure 1; Table 1).

SAS was subjected to a heat treatment in a growing room ("cook out") and then to a maturation treatment which consisted of a controlled recomposting process

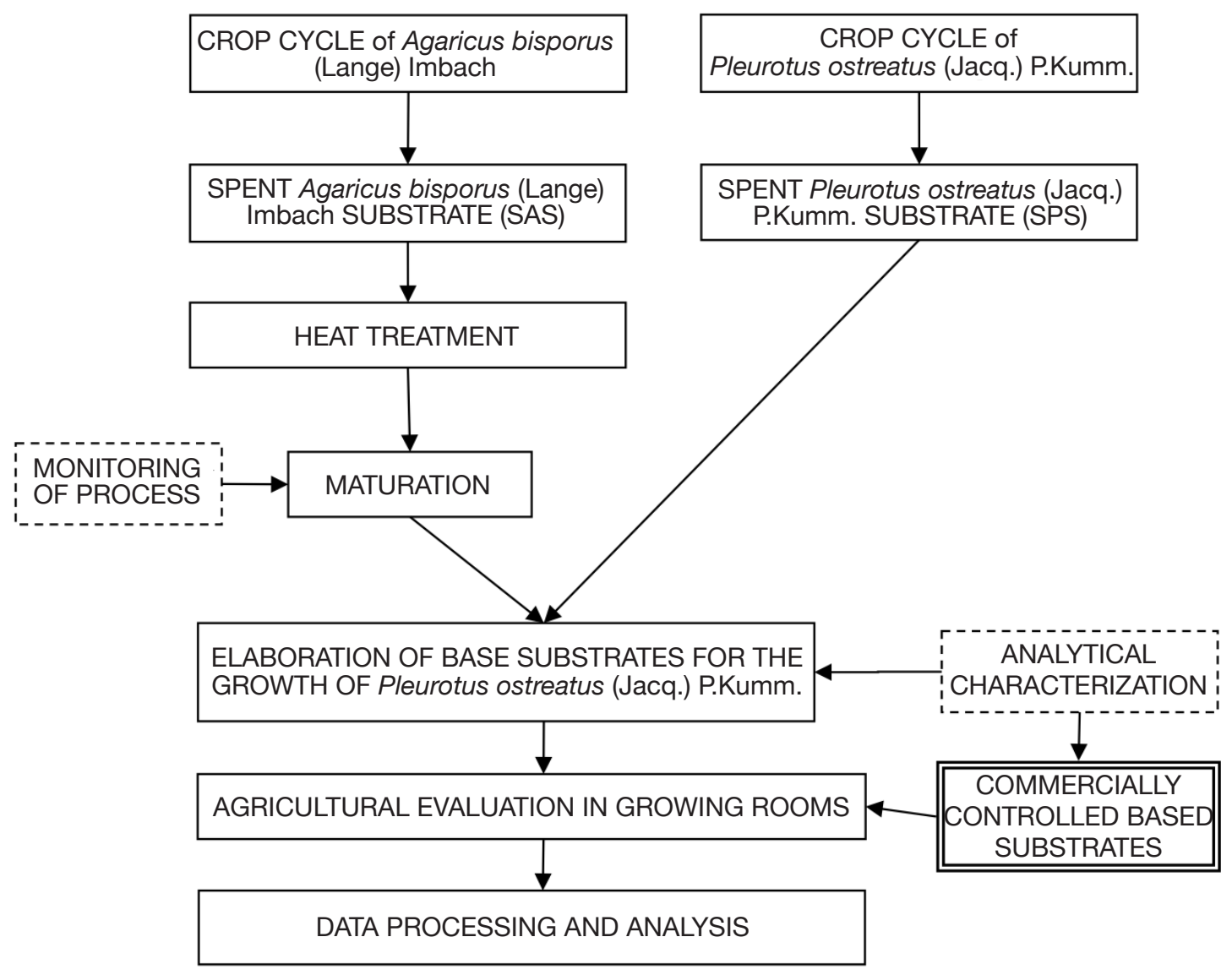

Figure 1. Schematic experiment approach - Approche expérimentale schématique. 
Table 1. Formulations tested (g per bag) in the experiment - Formulations testées ( $g$ par sac) dans l'expérience.

\begin{tabular}{llcl}
\hline Treatment & SPS & SAS & GYPSUM \\
\hline T1 & 6,000 & 0 & 300 \\
T2 & 5,400 & 600 & 300 \\
T3 & 4,800 & 1,200 & 300 \\
T4 & 4,200 & 1,800 & 300 \\
T5 & 3,600 & 2,400 & 300 \\
T6 & 3,000 & 3,000 & 300 \\
T7 & Commercially controlled based \\
& substrates (6.5 kg per bag) \\
\hline
\end{tabular}

T: treatment - traitement; SPS: spent Pleurotus ostreatus (Jacq.) P. Kumm. substrate - substrat épuisé de Pleurotus ostreatus (Jacq.) P. Kumm.; SAS: spent Agaricus bisporus (Lange) Imbach. substrate - substrat épuisé de Agaricus bisporus (Lange) Imbach.

in cameras. SPS was from Champymar (Quintanar del Rey, Cuenca) which was initially obtained from fresh wheat straw (maximum one week in empty rooms). Materials were mixed and the moisture content was adjusted. Then a pasteurizing heat treatment $\left(60^{\circ} \mathrm{C}-\right.$ $65^{\circ} \mathrm{C}, 8 \mathrm{~h}$ ) was performed. Afterwards, the temperature was decreased to the "seeding" temperature $\left(25^{\circ} \mathrm{C}\right)$ over $15 \mathrm{~h}$. Finally, supplementation and "seeding" (dose $30 \mathrm{~g} \cdot \mathrm{kg}^{-1}$ mycelium Fungisem K-15) were performed and the samples were bagged in the Center for Research, Experimentation and Mushroom Services' (CIES) pilot plant.

All substrates were packed into transparent polyethylene bags of $29 \mathrm{~cm}$ in diameter with heights ranging from 25 to $35 \mathrm{~cm}$, according to the type of substrate, totaling approximately $6.5 \mathrm{~kg}$ of weight. Four holes of $2.2 \mathrm{~cm}$ in diameter were uniformly drilled over the side of the bags.

\subsection{Driving and monitoring of the crop cycle}

The total research time was 70 days. The experiment was carried out at the CIES, located in the town of Quintanar del Rey (Cuenca, Spain) in an experimental greenhouse controlled for temperature, substrate temperature, relative humidity, and carbon dioxide concentration, and followed the recommended ranges for the variety of selected mycelium in each stage of development (CIES, 2007).

A controlled recomposting process was carried out consisting of a heat treatment in the growing room. Since air heats faster than the substrate, the air reached the maximum temperature $\left(71^{\circ} \mathrm{C}\right)$ in $19 \mathrm{~h}$, whereas the substrate reached this temperature in $22 \mathrm{~h}$. The duration of these high temperatures also differs from one medium to another. The maximum temperature of the air and of the substrate stabilizes for 7 and $3 \mathrm{~h}$, respectively. After the heat treatment, the temperature is decreased. The air temperature fell more rapidly than the substrate temperature causing the second to be above the first. Finally, these temperatures equilibrate to $34-38{ }^{\circ} \mathrm{C}$ after $31 \mathrm{~h}$.

During recomposting and maturation, the moisture content of the mass was maintained at $500 \mathrm{~g} \cdot \mathrm{kg}^{-1}$ without leaching. In this ripening process, the evolution of the moisture content in non-intervened composting had values that ranged from $527 \mathrm{~g} \cdot \mathrm{kg}^{-1}$ (in the beginning) and $504 \mathrm{~g} \cdot \mathrm{kg}^{-1}$ (at the end).

Substrate incubation lasted approximately 17 days (without external ventilation or lighting). During the incubation period, the relative humidity inside the greenhouse ranged between $90 \%$ and $95 \%$, while the substrate temperature was between $16^{\circ} \mathrm{C}$ and $23.78^{\circ} \mathrm{C}$. The room temperature ranged between $18{ }^{\circ} \mathrm{C}$ and $22^{\circ} \mathrm{C}$ to help control the temperature of the formulations. After this, fruiting was induced by ventilation (to keep $\mathrm{CO}_{2}$ levels regulated between $0.28 \%$ to $0.10 \%$ ), and the reduction of room temperature $\left(21.57^{\circ} \mathrm{C}\right.$ to $\left.13.63{ }^{\circ} \mathrm{C}\right)$, substrate temperature $\left(23.78^{\circ} \mathrm{C}\right.$ to $\left.14.73{ }^{\circ} \mathrm{C}\right)$, humidity (91\% to $94.50 \%$ ), and lighting. These values are similar to the microclimatic conditions recommended by other researchers (Pardo et al., 2005b; García Rollán, 2007; Pardo et al., 2007; Gregori et al., 2008; López-Rodríguez et al., 2008; Gea et al., 2009; Kurt et al., 2010).

\subsection{Evaluation of parameters}

For the evaluation of quality parameters, fresh mushrooms of uniform size and maturity were used and selected on the most optimal day of the harvest period. The surface color of fruiting bodies was measured by reflection using a Minolta brand colorimeter, model CR-300, previously calibrated with a calibration plate CR-A43 ( $\mathrm{L}=96.12, \mathrm{r}-\mathrm{g}=-0.11, \mathrm{y}-\mathrm{b}=+2.66)$ and illuminant D65. To evaluate the mechanical properties of mushrooms, in terms of firmness, an analyzer (TAXT Plus of Stable Micro Systems) was used. To take this measurement the fruiting bodies were cut into small pieces $\left(\sim 4 \mathrm{~cm}^{2}\right)$ and were introduced into the 5-bladed Kramer Shear Cell (KS5), arranged in two adjacent uniform layers and tested at a constant speed of $2 \mathrm{~mm} \cdot \mathrm{s}^{-1}$; thus breaking strength (Bs) was obtained, defined as the maximum force required to tear the fruiting bodies (expressed in N). Protein content in the carpophores was calculated by multiplying the total nitrogen content by a conversion factor of 4.38 (Delmas, 1989). Total nitrogen content was determined by the Kjeldahl method (TECATOR, 1987; MAPA, 1994). Ash content was determined by a direct calcination of the samples at $540{ }^{\circ} \mathrm{C}$ (MAPA, 1994). 
Depending on the level of spawn run time of the substrate by the mycelium and tested contaminations, a parameter was established designated as the germination index (GI), on a scale from 0 (no invasion) to 5 (full invasion).

The earliness was established as the time in days since the "seeding" of the substrate to the first flush harvested (weighing the daily relative production of the substrate). A flush corresponds to each production cycle that is repeated rhythmically during the harvest.

\subsection{Statistical analysis}

To carry out the statistical analysis, two software packages were used: Statgraphics ${ }^{\circledR}$ Plus version 5.1 (Statistical Graphics Corp., 2001) and SPSS ${ }^{\circledR}$ (SPSS, 2004). Descriptive statistical techniques, principal component analysis, variance analysis and correlation and regression methods were used to evaluate the data. Differences were considered significant for $p<0.05$.

\section{RESULTS AND DISCUSSION}

\subsection{Analytical characterization of the base materials used and the formulations}

The chemical characteristic results of the different source materials, formulations, and commercially controlled based substrates are shown in table 2. Growth and nutritional value of genus Pleurotus spp. mushrooms depend mainly on the type of substrate and growing conditions (Curvetto et al., 2002), but also on the treatments applied to made substrates and the growing mycelium (Pardo et al., 2005a). These considerations are also valid for other edible fungi, for example, L. edodes ("shiitake") (Philippoussis et al., 2002; Ozcelik et al., 2007).

The final values obtained after the SAS recomposing process were adjusted to the optimum range considered for this process (Lohr et al., 1984; Szmidt, 1994; Raymond et al., 1997). Higher concentrations of $\mathrm{P}, \mathrm{K}, \mathrm{Ca}$, and $\mathrm{Mg}$ in the cover layer (Raymond et al., 1997) and a higher ash content (which contributes greatly to the cover layer of mineral soil) (Stewart et al., 1977; Lohr et al., 1984) were observed, when compared to the control substrate.

In this experiment, the chemical characterization was studied using two different base materials in the made substrates. Increasing doses of SAS increase the $\mathrm{pH}$ from 5.88 to 8.07 and the ash content from $27.66 \%$ to $50.88 \%$. In contrast, this treatment decreases moisture content from $75.60 \%$ to $72.50 \%$, organic matter from $72.34 \%$ to $49.12 \%, \mathrm{C} / \mathrm{N}$ from

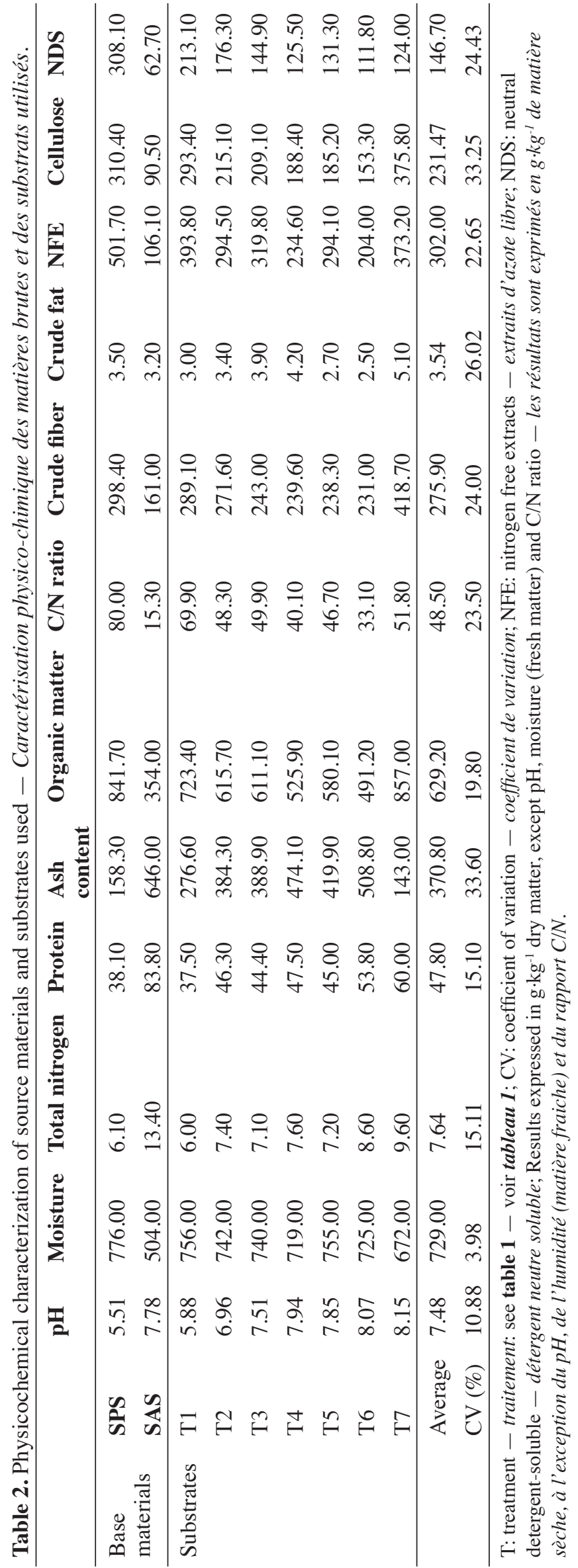


69.90 to 33.10 , crude fiber from $28.91 \%$ to $23.10 \%$, NFE from $39.38 \%$ to $20.40 \%$, cellulose from $29.34 \%$ to $15.33 \%$ and NDS decreases from $21.31 \%$ to $11.18 \%$.

\subsection{Production qualitative parameters. Descriptive statistics and ANOVA}

In table 3, descriptive statistics of crude protein and ash contents, as well as brightness values (L), redgreen ( $r-g)$ and yellow-blue (y-b) chromaticity, Bs, and $\mathrm{CE}_{\mathrm{E}}$ in the harvested mushrooms are shown.

Of the six treatments with different spent substrate mixtures, T1 consisting of $6,000 \mathrm{~g}$ of SPS, showed difficulties in germination, mycelial development, and growth arrest, saw a high degree of contamination by Gliocladium spp. (which can be associated to the low $\mathrm{pH}$ of the substrate, Table 2), and did not produce $P$. ostreatus cultivation.

Overall, proteins are the most critical components that contribute to the nutritional value of a food, and fungi are a good source of them (Crisan et al., 1978).

Most of the interest in the nutritional value of mushrooms is related to the nutritional quantity and quality of proteins (Manning, 1985). The mushroom's protein content values achieved in this experiment ranged between $15.48 \%$ (T2) and $20.70 \%$ (commercial substrate, T7) (Table 3) are lower than those obtained by Rodríguez Barreal (1987) (31\%) and Benavides et al. (2009) (34.09\%).

Many supplements such as cottonseed powder and rice bran (rich in nitrogen) are ideal for increasing yields and quality of the mushrooms (Jandaik,
1989). Organic supplements such as soybean meal, alfalfa, and cotton seed powder and meal, not only increase yields, but also the mushrooms protein content (Zadrazil, 1980a; Zadrazil, 1980b). Forero et al. (2008) argue that there is a positive correlation between the nitrogen and protein contents of the fungi substrate, due to the importance of the macroelement as a nutrient for the growth and development of the fungus.

The protein content values obtained in this experiment were lower than those obtained with P. ostreatus and P. sajor-caju by Basak et al. (1996), Wang et al. (2001) and Mandeel et al. (2005) (between $17.80 \%$ and $23.30 \%$ ). As well as those obtained using pepper residues as substrates (between $15.60 \%$ and $28.60 \%$ ) (Forero et al., 2008).

Higher values in P. ostreatus were obtained by Pardo et al. (2005a) in terms of protein content depending on the substrate type, treatment, and mycelium used (from $14.04 \%$ to $17.75 \%$ ). Pardo et al. (2007), also using P. ostreatus, got similar values of those in this experiment in terms of protein content depending on the different types of substrate and treatment used (from 19.07\% to 23.98\%). Pardo et al. (2008), working with P. ostreatus, got different mushroom protein content values, depending on the type of substrate, substrate treatment, and the weight of the bag used (from $14 \%$ to $26.30 \%$ ).

Likewise, higher values than this experiment (between $\mathrm{T} 2=15.48 \%$ and $\mathrm{T} 6=18.79 \%$ ) were obtained by Bermudez et al. (2007) on Pleurotus spp. in blends of coffee pulp + cedar chips with the

Table 3. Physicochemical characterization of Pleurotus fruiting bodies grown on the different formulations - Caractérisation physico-chimique des fructifications de Pleurotus cultivées sur les différents substrats.

\begin{tabular}{|c|c|c|c|c|c|c|c|}
\hline \multirow[t]{2}{*}{ Substrate } & \multirow{2}{*}{$\begin{array}{l}\text { Crude protein } \\
\left(\mathrm{g} \cdot 100 \mathrm{~g}^{-1}\right)\end{array}$} & \multirow{2}{*}{$\begin{array}{l}\text { Ash content } \\
\left(\mathrm{g} \cdot 100 \mathrm{~g}^{-1}\right)\end{array}$} & \multicolumn{3}{|l|}{ Color } & \multirow[t]{2}{*}{ Bs (N) } & \multirow[t]{2}{*}{$\mathrm{CE}(\mathrm{mJ})$} \\
\hline & & & $\mathbf{L}$ & r-g & $\mathbf{y}-\mathbf{b}$ & & \\
\hline $\mathrm{T} 2$ & $15.48^{b}$ & $5.84^{c}$ & 72.89 & $1.46^{\mathrm{b}}$ & $11.72^{\mathrm{a}, \mathrm{b}}$ & $314.54^{\mathrm{a}, \mathrm{b}}$ & $1.308 .87^{b}$ \\
\hline $\mathrm{T} 3$ & $16.14^{\mathrm{b}}$ & $6.37^{\mathrm{b}}$ & 74.20 & $2.12^{\mathrm{a}, \mathrm{b}}$ & $9.66^{\mathrm{b}}$ & $310.50^{\mathrm{a}, \mathrm{b}}$ & $1.350 .50^{\mathrm{b}}$ \\
\hline $\mathrm{T} 4$ & $15.73^{b}$ & $6.89^{\mathrm{a}}$ & 72.41 & $2.53^{\mathrm{a}, \mathrm{b}}$ & $11.99^{\mathrm{a}, \mathrm{b}}$ & $303.14^{\mathrm{b}}$ & $1.351 .97^{\mathrm{b}}$ \\
\hline T5 & $17.22^{\mathrm{a}, \mathrm{b}}$ & $7.24^{\mathrm{a}}$ & 73.38 & $2.96^{\mathrm{a}}$ & $14.21^{\mathrm{a}}$ & $319.71^{\mathrm{a}, \mathrm{b}}$ & $1.429 .01^{\mathrm{a}, \mathrm{b}}$ \\
\hline T6 & $18.79^{\mathrm{a}, \mathrm{b}}$ & $7.46^{\mathrm{a}}$ & 74.22 & $2.67^{\mathrm{a}, \mathrm{b}}$ & $14.70^{\mathrm{a}}$ & $350.96^{\mathrm{a}}$ & $1.649 .30^{\mathrm{a}}$ \\
\hline $\mathrm{T} 7$ & $20.70^{\mathrm{a}}$ & $6.67^{\mathrm{a}, \mathrm{b}}$ & 70.90 & $2.09^{\mathrm{a}, \mathrm{b}}$ & $11.94^{\mathrm{a}, \mathrm{b}}$ & $279.43^{\mathrm{b}}$ & $1.294 .96^{\mathrm{b}}$ \\
\hline Average & 17.34 & 6.74 & 73.00 & 2.31 & 12.37 & 313.05 & 1.397 .43 \\
\hline Fisher F & 6.41 & 7.15 & 0.99 & 2.85 & 4.30 & 5.57 & 5.40 \\
\hline $\mathrm{S}_{\mathrm{L}}$ & $0.001 * * *$ & $0.001 * * *$ & $0.45 \mathrm{~ns}$ & $0.05^{*}$ & $0.01 * *$ & $0.003 * *$ & $0.003 * *$ \\
\hline
\end{tabular}

T: treatment - traitement: see table 1 - voir tableau 1; L: brightness - luminosité; r-g: red-green color components - composants de couleur rouge-vert; $\mathrm{y}$-b: yellow-blue color components - composants de couleur jaune-bleu; Bs: breaking strength - résistance à la rupture; $\mathrm{CE}$ : compression energy - énergie de compression; $\mathrm{S}_{\mathrm{L}}, \mathrm{F}$ : significance level, Fisher - niveau de signification Fisher; ns: no significant difference - aucune différence significative, $p$-value $>0.05 ; *$ : $p$-value $<0.05 ; * *$ : $p$-value $<0.01 ; * *$ : $p$-value $<0.001$; for each column, values followed by different letters are significantly different from each other - dans chaque colonne, les valeurs suivies de lettres différentes sont significativement différentes les unes des autres ( $p=0.05$, Tukey-HSD). 
strains CCEBI 3021 and CCEBI 3027: 27\% and 34\%, respectively; substrates on coffee pulp: $30 \%$ and $38 \%$, respectively; and substrates based on cedar chips: $21 \%$ and $22 \%$, respectively. Fonseca et al. (2009) also achieved higher values in protein content using as substrates, a mixture of rice bran (40\%), rice straw (35\%) and Juncus effusus L. (25\%) in the growing of P. ostreatus (30.52\%).

Similar values for protein content to those obtained in this experiment were achieved by Oyetayo et al. (2004) working with P. sajor-caju, comparing the protein content of mushrooms grown in substrates of grated cobs $(17.49 \%)$ and without supplementation (14.94\%) and, similar values in P. eryngii, Manzi et al. (2004) (22.20\%), and Hassan et al. (2010): sawdust $(22.17 \%)$, soybean straw $(24.08 \%)$, sugar cane bagasse $(21.33 \%)$ and rice straw $(22.75 \%)$.

The ash content of the mushrooms obtained in this experiment ranged between $5.84 \%$ (T2) and $7.46 \%$ (T6) (Table 3). These values are similar to those given on average by Rodriguez Barreal (1987) (7.50\%) and Benavides et al. (2009) (5.55\%). Other researchers, such Basak et al. (1996), Manzi et al. (1999), Wang et al. (2001) and Shashirekha et al. (2002) expanded the range of these contents between $6.70 \%$ and $15.40 \%$. Baena (2005), working with green manguey bagasse in mushrooms of P. ostreatus, got ash content values ranging between $3.77 \%$ and $8.73 \%$. Siwulski et al. (2009), also working with P. ostreatus, but with alder sawdust substrates supplemented with leaves of two different species of Ginkgo biloba L., concluded that the addition of G. biloba leaves does not affect the ash content of fruiting bodies.

Pardo et al. (2005a), on research carried out in Castilla La Mancha with P. ostreatus obtained similar ash content values in mushrooms to this experiment, depending on the type of substrate, treatment, and mycelium used (from $6.83 \%$ to $7.70 \%$ ). In the same range of P. ostreatus ash content values, Pardo, in a later work (Pardo et al., 2007), achieved different ash values in the carpophores (from 6\% to $7.14 \%$ ).

In another study, also with P. ostreatus, the same researchers (Pardo et al., 2008) obtained different values for ash content depending on the type of substrate, treatment, and weight of the bag used (from $5.80 \%$ to $7.50 \%$ ). These authors found no significant differences between the dry matter content and ash of fruiting bodies obtained from the various combinations, although they noticed a lower protein content in the most productive mixtures.

Similarly, slightly higher values of ash content than those obtained in this experiment were achieved by Forero et al. (2008). Growing P.ostreatus on waste chili, they reached values between $8.81 \%$ and $9.84 \%$, justifying these figures by the high ash content of supplied based substrates. Similar values were obtained by Fonseca et al. (2009), using a mixture of rice straw (35\%), Juncus effusus L. (25\%) and rice bran (40\%), achieving an ash content value of $6.38 \%$ by growing $P$. ostreatus.

In other Pleurotus species, such as P. eryngii, Manzi et al. (1999) using substrates based on wheat straw + beet $(15 \%)$, reached ash content values between $6.90 \%$ and $10.50 \%$. Manzi et al. (2004) achieved in the same species, an ash content of $1.20 \%$ (based on the fresh product with $86.60 \%$ moisture). Also, in P. eryngii, Hassan et al. (2010) obtained different ash content values with various substrates: sawdust $(6.94 \%)$, soybean straw $(7.66 \%)$, sugar cane bagasse $(6.54 \%)$ and rice straw $(8.02 \%)$. In P. sajor-caju, Oyetayo et al. (2004) reached ash content values of $10.51 \%$ in mushrooms when cultivated with substrates of grated ears, which decays to $7.41 \%$ without supplementation.

In other types of fungi, for instance, Ganoderma lucidum (Curt.: Fr.) P. Karst, the moisture, protein, and ash contents are very different from the values of the same parameters in Pleurotus spp. Peksen et al. (2009), working with this fungus and different combinations of sawdust substrates (wheat bran and tea waste) obtained lower values in these three quality parameters than those obtained in this experiment and collected by the literature for $P$. ostreatus.

In general, according to color and texture, mushrooms produced in the substrates of this experiment show similar features achieved by Urbano et al. (2002), Rodriguez Valencia et al. (2005) and Forero et al. (2008). For the consumer, the color and texture of the mushrooms are paramount (Matser et al., 2000). Unacceptable changes in these factors can produce a loss of consumer acceptability.

In regards to color, the commercial substrate (T7) had the smallest values in lightness (L) (70.90). The brightest substrates were achieved with T3 (74.20) and T6 (74.22) with T4 (72.41) and T2 (72.89) following close behind (Table 3). The substrates with the highest value in the red-green component $(\mathrm{r}-\mathrm{g})$ were those that reduced the amount of SPS and increased the SAS until balanced. The highest values of redgreen component $(\mathrm{r}-\mathrm{g})$ were achieved with T4 (2.53) and T5 (2.96) while T7 (2.09) and T2 (1.46) were the lowest. Similarly, these considerations are valid for yellow-blue component (y-b). The highest values of yellow-blue component $(\mathrm{y}-\mathrm{b})$ were achieved with $\mathrm{T} 4$ (11.99) and T6 (14.70) while T2 (11.72) and T3 (9.66) were the lowest (Table 3).

Texture (hardness, cohesiveness, springiness, and chewiness) was controlled in Pleurotus spp. cultivated on rice straw (Kotwaliwale et al., 2007). According to these authors, the increase in hardness and chewiness, and the decrease in cohesion and elasticity in these mushrooms can be attributed to the loss of moisture in the mushroom bodies. 


\subsection{Correlation matrix and "step by step" regression models}

T1 $(6,000 \mathrm{~g}$ SPS) showed difficulties in germination and a high degree of contamination by Gliocladium spp. Due to these reasons, T1 was not considered in the statistical analysis of this experiment.

Table 4 presents the correlation matrix between production parameters and physicochemical properties of the substrates prepared in this experiment. Cellulose content of processed substrates correlates significantly with protein and ash contents and CE. Also, the ash content and the red-green component ( $\mathrm{r}-\mathrm{g}$ ) are positively correlated with the $\mathrm{pH}$ of the mixtures.

Table 5 presents the correlation matrix between production and qualitative parameters, GI, the earliness, and quantitative production parameters. Higher GI values corresponded with a decrease in all harvested mushrooms qualitative parameters. Additionally, statistically significant negative correlations were observed with dry matter, protein content, Bs and CE. In contrast, the days from inoculation until the appearance of the first primordia are positively correlated with all quality parameters, although only significantly with the unit weight, ash content and the yellow-blue component (y-b) of mushrooms. Finally, $\mathrm{BE}$ is negatively correlated with all quality parameters, although, only significantly with the ash content and the yellow-blue component (y-b) of mushrooms.

Correlating with other quality parameters, a higher dry matter content in mushrooms corresponds with higher protein, Bs, and CE values (Table 6).

Table 7 presents the "step by step" regression models for qualitative production parameters depending on the physicochemical properties of the substrates made, GI, earliness, and production characteristics of quantitative parameters. The model that best explains the variability of the mushroom's protein content is one that includes the GI $\left(\mathrm{R}^{2}=93.30 \%\right)$, although, with increasing GI, this content is reduced. Also, cellulose and hemicellulose contents, and the yellow-blue component $(y-b)$ of the mushrooms provide good models to explain the variability of this qualitative parameter.

The best model explaining the variability of ash content include the $\mathrm{pH}$ of processed substrates (positive coefficient) and crude fat (negative coefficient) as independent variables $\left(\mathrm{R}^{2}=99.00 \%\right)$.

Mathematical models for the $\mathrm{CE}$ variability include the GI (negative coefficient; $\mathrm{R}^{2}=97.60 \%$ ), the cellulose content of made substrates (negative coefficient; $\mathrm{R}^{2}=$ $84.20 \%$ ) and dry matter (positive coefficient, $\mathrm{R}^{2}=$ $95.50 \%)$.

Ash and cellulose contents of the preparated substrates are two independent variables that explain, suitably, the variability of the red-green component ( $\mathrm{r}-\mathrm{g})$ (positive coefficients), while the quantity of

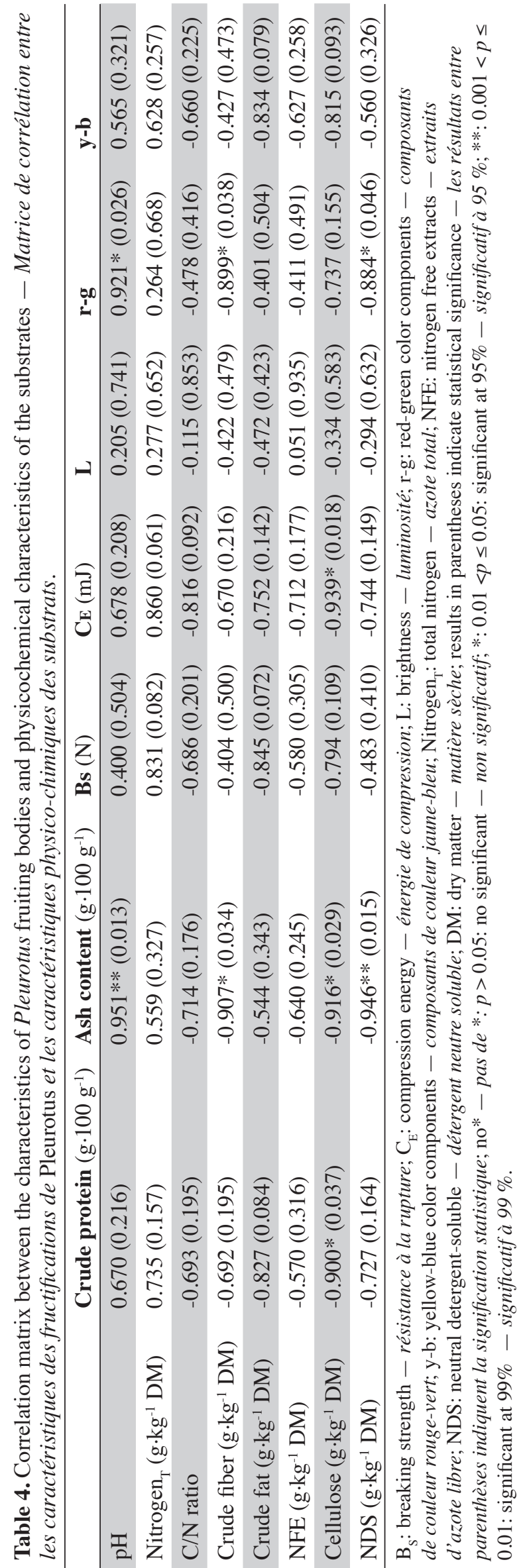




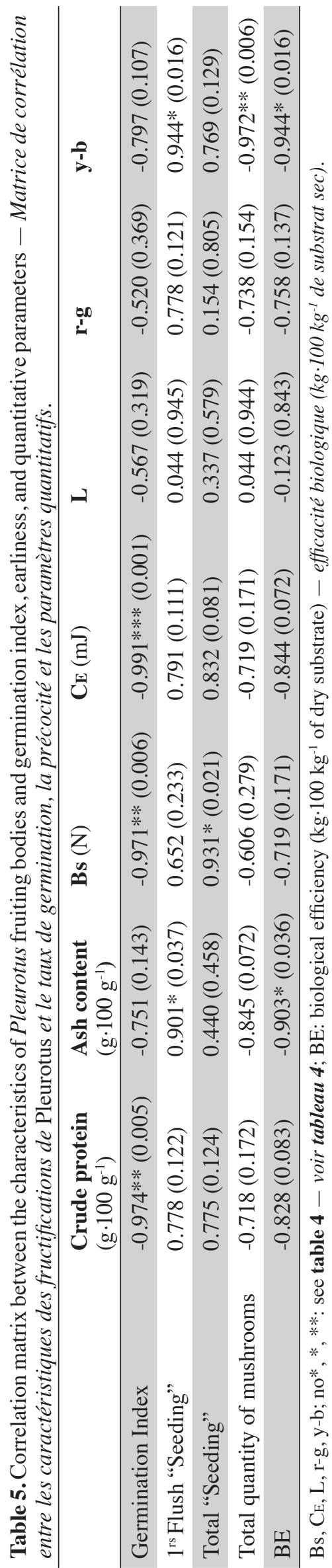

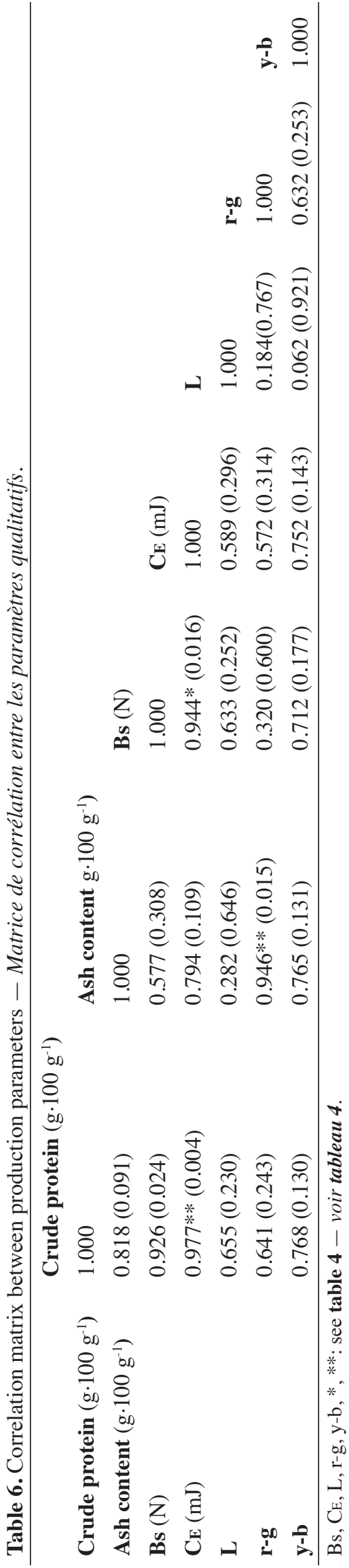

mushrooms produced and $\mathrm{BE}$ (negative coefficients) explain the yellow-blue component $(y-b)$ (Table 7).

\section{CONCLUSIONS}

According to the results obtained for the combinations tested, SPS $(3,600 \mathrm{~g})+$ SAS $(2,400 \mathrm{~g})$ and SPS $(3,000 \mathrm{~g})+$ SAS $(3,000 \mathrm{~g})$ were prepared substrates that achieved acceptable crude protein content in fruiting bodies. With these substrates, higher ash content, lightness, yellow-blue (y-b) and red-green (r-g) chromaticity, breaking strength (Bs) and compression energy (CE) were obtained. These values were higher than the mean values and even higher than the commercial substrate. Increased SAS participation in the mixture of the processed substrate (and the consequent reduction of SPS participation) resulted in mushrooms that require higher Bs and $\mathrm{CE}$ for the cultivation of fruiting bodies.

Consequently, these formulation based composts degraded by the growth of P. ostreatus could be a low-cost substrate with selective and balanced nutrients for growth and development of oyster mushrooms. This material could be integrated through new formulations and methodologies while lowering production costs and reducing the environmental impact of unusual waste.

\section{Bibliography}

ANKOM, 2005. Method for determining acid detergent lignin in beakers. ANKOM Technology method AK $8 / 05$. Macedon, NY, USA: ANKOM Technology.

ANKOM, 2006a. Neutral detergent fiber in feeds. Filter bag technique. ANKOM Technology method 6. Macedon, NY, USA: ANKOM Technology.

ANKOM, 2006b. Acid detergent fiber in feeds. Filter bag technique. ANKOM 




Technology Method 5. Macedon, NY, USA: ANKOM Technology.

ANKOM, 2008. Crude fiber analysis in feeds by filter bag technique. AOCS Approved Procedure Ba 6 05, ANKOM Technology Method 7. Macedon, NY, USA: ANKOM Technology.

ANKOM, 2009. Rapid determination of oil/fat utilizing high temperature solvent extraction. ANKOM Technology method 2, AOCS Official Procedure Am 5-04. Macedon, NY, USA: ANKOM Technology.

Ansorena J., 1994. Sustratos. Propiedades y Caracterización. Madrid, España: Ed. MundiPrensa, S.A.

Baena A., 2005. Aprovechamiento del bagazo del manguey verde (Agave salmiana) de la agroindustria del mezcal en San Luís Potosí para la producción del Hongo ostra (Pleurotus ostreatus). Trabajo de grado (Maestro en Ciencias Aplicadas): Instituto Potosino de Investigación Científica y Tecnologíca, A.C., San Luís Potosí (México).

Basak M.K. et al., 1996. Recycling jute waste for edible mushroom production. Ind. Crops Prod., 5, 173-176.

Benavides J.S. \& Herrera J.C., 2009. Reconocimiento de las características del género Pleurotus spp. y sus aplicaciones. Manizales, Colombia: Colegio Seminario Redentorista San Clemente Maria Hofbauer.

Bermúdez R.C., García Oduardo N. \& Mourlot A., 2007. Fermentación sólida para la producción de Pleurotus sp. sobre mezclas de pulpa de café y viruta de cedro. Tecnol. Quím., 27, 55-62.

Bonatti M., Karnopp P., Soares H.M. \& Furlan S.A., 2004. Evaluation of Pleurotus ostreatus and Pleurotus sajor-caju nutricional characteristics when cultivated in different lignocellulosic wastes. Food Chem., 88, 425-428.

Brizuela M.A., García L., Pérez L. \& Mansur M., 1998. Basidiomicetos: nueva fuente de metabolitos secundarios. Rev. Iberoam. Micol., 15, 69-74.

Chang S.T. \& Miles P., 1997. Biología de las Setas. Fundamentos Básicos y Acontecimientos Actuales. Hong Kong, China: World Scientific.

CIES, 2007. Relación de variedades comerciales de setas Pleurotus y otros hongos exóticos. In: Diputación Provincial de Cuenca, ed.El Champiñón en Castilla - La Mancha. Boletín informativo 25. Quintanar del Rey, Cuenca, España: Centro de Investigación, Experimentación y Servicios del Champiñón.

Crisan E.V. \& Sands A., 1978. Nutrition value. In: Chang S.T. \& Hayes W.A., eds. The biology and cultivation of edible mushrooms. New York, NY, USA: Academic Press, 137-168. 
Curvetto N.R., Figlas D., Devalis R. \& Delmastro S., 2002. Growth and productivity of different Pleurotus ostreatus strains on sunflower seed hulls supplemented with

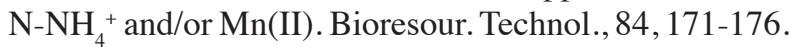

Delmas J., 1989. Les champignons et leur culture. Paris : Flammarion-La Maison Rustique.

Faraco V. et al., 2009. Bio-remediation of colored industrial wastewaters by the white-rot fungi Phanerochaete chrysosporium and Pleurotus ostreatus and their enzymes. Biodegradation, 20, 209-220.

Fonseca G.G. et al., 2009. Protein enrichment and digestibility of soft rush (Juncus effusus) and rice residues using edible mushrooms Pleurotus ostreatus and Pleurotus sajor-caju. World J. Microbiol. Biotechnol., 25, 449-456.

Forero C.L., Hoyos O.L. \& Bazante W.E., 2008. Evaluación de residuos de ají (Capsicum spp.) como sustrato en la producción de setas comestibles (Pleurotus ostreatus). Fac. Cienc. Agropecu., 6, 42-53.

García Rollán M., 2007. Cultivo de setas y trufas. $5^{\text {th }}$ ed. Madrid: Mundi - Prensa, S.A.

Gea F.J., Martínez-Carrasco A. \& Navarro M.J., 2009. Efecto de la suplementación del sustrato sobre la cosecha de setas. Hortic. Int., 67, 32-40.

González J., Alvira P. \& González G., 1987. La cascarilla de arroz en la alimentación animal. II. Composición químico-bromatológica. Rev. Agroquím. Tecnol. Aliment., 27, 139-149.

Gregori A. et al., 2008. The use of spent brewery grains for Pleurotus ostreatus cultivation and enzyme production. New Biotechnol., 25, 157-161.

Hassan F.R.H., Medany G.M. \& Abou Hussein S.D., 2010. Cultivation on the king oyster mushroom (Pleurotus eryngii) in Egypt. Aust. J. Basic Appl. Sci., 4, 99-105.

Jandaik C.L., 1989. Response of Pleurotus sajor-caju to supplementation prior to and after pasteurisation of straw. Indian Phytopathol., 42, 284-285.

Khanna P. \& Garcha H.S., 1982. Utilization of paddy straw for cultivation of Pleurotus species. Mushroom Newsl. Trop., 2, 5-9.

Kotwaliwale N., Bakane P. \& Verma A., 2007. Changes in textural and optical properties of oyster mushroom during hot air drying. J. Food Eng., 78, 1207-1211.

Krantz G.W., 1986. A manual of acarology. $2^{\text {nd }}$ ed. Corvallis, OR, USA: Oregon State University Book Stores, Inc.

Kuforiji O.O. \& Fasidi I.O., 2008. Enzyme activities of Pleurotus tuber-regium (Fries) Singer, cultivated on selected agricultural wastes. Bioresour. Technol., 99, 4275-4278.

Kurt S. \& Buyukalaca S., 2010. Yield performances and changes in enzyme activities of Pleurotus spp. (P. ostreatus and P. sajor-caju) cultivated on different agricultural wastes. Bioresour. Technol., 101, 3164-3169.

Lohr V.L., Wang S.H. \& Wolt J.D., 1984. Physical and chemical characteristics of fresh and aged spent mushroom compost. HortScience, 19, 681-683.
López-Rodríguez C., Hernández-Corredor R., SuárezFranco C. \& Borrero M., 2008. Evaluación del crecimiento y producción de Pleurotus ostreatus sobre diferentes residuos agroindustriales del Departamento de Cundinamarca. Univ. Scientiarum, 13, 128-137.

Mandeel Q.A., Al-Laith A.A. \& Mohamed S.A., 2005. Cultivation of oyster mushrooms (Pleurotus spp.) on various lignocellulosic wastes. World J. Microbiol. Biotechnol., 21, 601-607.

Manning K., 1985. Food value and chemical composition. In: Flegg P.B., Spencer D.M. \& Wood D.A., eds. The biology and technology of the cultivated mushrooms. Chichester, UK: John Wiley \& Sons Ltd., 211-230.

Manzi P. et al., 1999. Nutrients in edible mushrooms: an interspecies comparative study. J. Food Chem., 65, 477482.

Manzi P., Marconi S., Aguzzi A. \& Pizzoferrato L., 2004. Commercial mushrooms: nutritional quality and effect of cooking. Food Chem., 84, 201-206.

MAPA, 1994. Métodos Oficiales de Análisis. Tomo III. Madrid: Servicio de Publicaciones del Ministerio de Agricultura, Pesca y Alimentación.

Matser A.M., Knott E.R., Teunissen P.G.M. \& Bartels P.V., 2000. Effects of high isostatic pressure on mushrooms. J. Food Eng., 45, 11-16.

Medina E. et al., 2009. Spent mushroom substrates as component of growing media for germination and growth of horticultural plants. Bioresour. Technol., 100, 4227-4232.

Muez M.A. \& Pardo J., 2002. La preparación del sustrato. In: Sánchez J.E. \& Royse D., eds. La biología y el cultivo de Pleurotus spp. Limusa, México: Ecosur, 157-186.

Nombela G. \& Bello A., 1983. Modificaciones al método de extracción de nematodos fitoparásitos por centrifugación en azúcar. Bol. Serv. Plagas, 9, 183-189.

Oyetayo F.L. \& Akindahunsi A.A., 2004. Nutrient distribution in wild and cultivated edible mushroom, Pleurotus sajo-caju. Food Agric. Environ., 2, 166168.

Ozcelik E. \& Peksen A., 2007. Hazelnut husk as a substrate for the cultivation of shiitake mushroom (Lentinula edodes). Bioresour. Technol., 98, 2652-2658.

Pardo A., Perona M.A. \& Pardo J., 2005a. Evaluación de nuevos materiales en la elaboración de sustratos específicos para el cultivo de Pleurotus ostreatus (Jacq. ex Fr.) Kummer. Cuad. Fitopatol., 85, 77-83.

Pardo A., Perona M.A. \& Pardo J., 2005b. Utilización de raspón de uva en la elaboración de sustratos específicos para el cultivo de Pleurotus ostreatus (Jacq. ex Fr.) Kummer. ITEA, 101, 59-69.

Pardo A., Perona M.A. \& Pardo J., 2007. Nuevos materiales y tratamientos en la elaboración de sustratos para cultivo de Pleurotus ostreatus (Jacq. ex Fr.) Kummer. Cuad. Fitopatol., 91, 7-13.

Pardo A., Perona M.A. \& Pardo J., 2008. Evaluación de nuevos materiales en la elaboración de sustratos 
específicos para cultivo de Pleurotus ostreatus (Jacq. ex Fr.) Kummer. Cuad. Fitopatol., 85, 77-84.

Pardo A., Pardo J.E., Picornell M.R. \& de Juan J.A., 2009. Suplementación de sustratos degradados por el cultivo de Pleurotus ostreatus (Jacq.) P. Kumm. In: Resumen de las Actas del VI Congreso Ibérico de Ciencias Hortícolas, 25-29 Mayo 2009, Palacio de Congresos y Auditorio, La Rioja, España, 670-674.

Pathak H. et al., 2009. Global warming mitigation potential of biogas plants in India. Environ. Monit. Assess., 157, 407-418.

Peksen A. \& Yakupoglu G., 2009. Tea waste as a supplement for the cultivation of Ganoderma lucidum. World J. Microbiol. Biotechnol., 25, 611-618.

Philippoussis A., Diamantopoulou P. \& Zervakis G., 2002. Monitoring of mycelium growth and fructification of Lentinula edodes on several lignocellulosic residues. In: Sánchez J.E., Huerta G. \& Montiel E., eds. Mushroom biology and mushroom products. Cuernavaca, México: UAEM, 279-287.

Picornell M.R., de Juan J.A. \& Pardo A., 2010. Reutilización de sustratos postcultivo de hongos comestibles en el cultivo de Pleurotus ostreatus (Jacq.) P. Kumm. $\mathrm{PhD}$ thesis: Escuela Técnica Superior de Ingenieros Agrónomos de Albacete, Universidad de Castilla - La Mancha (España).

Raymond D.A., $\quad$ Varoney R.P. \& Chong C., 1997. Characteristics of composts derived from waxed corrugated cardboard. Compost Sci. Util., 5, 60-70.

Rodríguez Barreal J.A., 1987. El Pleurotus ostreatus, hongo comestible: su cultivo sobre sustratos lignocelulósicos. Madrid: Ed. Fundación Conde del Valle de Salazar, Escuela Técnica Superior de Ingenieros de Montes.

Rodríguez Valencia N. \& Jaramillo C., 2005. Cultivo de hongos comestibles del género Pleurotus sobre residuos agrícolas de la zona cafetera. Chinchiná, Caldas, Colombia: Cenicafé.

Sánchez C., 2010. Cultivation of Pleurotus ostreatus and other edible mushrooms. Appl. Microbiol. Biotechnol., 85, 1321-1337.

Savalgi V. \& Savalg V., 1994. Evaluation of substrates and supplements for three Pleurotus spp. Indian J. Mycol. Plant Pathol., 24, 190-191.

Shashirekha M.N., Rajarathnam S. \& Bano Z., 2002. Enhancement of bioconversion efficiency and chemistry of the mushroom, Pleurotus sajor-caju (Berk and Br.) Sacc. produced on spent rice straw substrate, supplemented with oil seed cakes. J. Agric. Food Chem., 76, 27-31.

Siwulski M., Czerwinska-Nowak A. \& Korszun S., 2009. Effect of addition of maidenhair tree leaves to substrate on yielding and chemical composition of Pleurotus ostreatus (Fr.) Kumm. carpophores. Veg. Crops Res. Bull., 71, 103-109.

SPSS, 2004. SPSS® 13.0 Brief Guide. Chicago, ILL, USA: SPSS.

Statistical Graphics Corporation, 2001. Statgraphics Plus® 5.1 for Windows. Herndon, VA, USA: Statistical Graphics Corporation.

Stewart B.A.\& Meek B.D., 1977. Soluble salt considerations with waste application. In: Soils for management of organic wastes and water wastes. Madison, WI, USA: Soil Science Society of America, 217-232.

Szmidt R.A.K., 1994. Recycling of spent mushroom substrates by aerobic composting to produce novel horticultural substrates. Compost Sci. Util., 2, 63-72.

Tajbakhsh J. et al., 2008. Trend of physico-chemical properties change in recycling spent mushroom compost through vermicomposting by epigeic earthworms Eisenia foetida and E. andrei. J. Agric. Technol., 4, 185198.

TECATOR, 1987. Determination of Kjeldahl nitrogen content with the Kjeltec auto 1030 analyzer. Tecator application Note 30/87. Hönagäs, Sweden: Tecator.

Urbano B.O.Z. \& Astaiza P., 2002. Determinación de una metodología para la utilización de residuos agrícolas (cascarilla de café, pasto de corte, espárrago, cainas de frijol y arveja) generados en el Municipio de Popayán y evaluación del efecto de los sustratos en la producción de setas (Pleurotus ostreatus). Trabajo de Grado (Ingeniero Agroindustrial): Facultad de Ciencias Agropecuarias, Departamento de Agroindustria, Universidad Del Cauca - Unicauca (Colombia).

Vijay M., Shyam P., Abrar S. \& Mirza B., 2007. Bioconversion of low quality lignocellulosic agricultural waste into edible protein by Pleurotus sajor-caju (Fr.) Singer. J. Zhejiang Univ. Sci., 8, 745-751.

Wang D., Sakoda A. \& Suzuki M., 2001. Biological efficiency and nutritional value of Pleurotus ostreatus cultivated on spent beer grain. Bioresour. Technol., 78, 293-300.

Zadrazil F., 1980a. Influence of ammonium nitrate and organic supplements on the yield of Pleurotus sajor-caju (Fr.) Sing. Eur. J. Appl. Microbiol. Biotechnol., 9, 31-35.

Zadrazil F., 1980b. Conversion of different plant wastes into feed by basidiomycetes. Eur. J. Appl. Microbiol. Biotechnol., 9, 243-248. 